\title{
STEREOTIP ISLAM TERORIS DALAM NOVEL “TELL YOUR FATHER THAT I AM A MOSLEM" KARYA HENGKI KUMAYANDI (Analisis Semiotika Roland Barthes)
}

\author{
Umi Rojiati ${ }^{1}$ \\ Hagi Julio Salas ${ }^{2}$ \\ ${ }^{1}$ Universitas Islam Negeri Raden Intan Lampung \\ ${ }^{2}$ Universitas Lampung \\ E-mail: umirojiati@radenintan.ac.id, hagijulio@gmail.com
}

\begin{abstract}
The novel becomes the author's media to express the problems found in the community then retold and add imagination so that it can attract readers. Novels are said to be beautiful if they contain messages, messages, ideas, and meanings that benefit the reader. The novel "Tell Your Father that I am a Moslem" contains, messages, ideas, and meanings that are beneficial to readers. The message will be expressed by Roland Barthes's semiotic theory, including: (a) the hermeneutic code includes: riddle, resentment, prejudice, responses from various events, answers, and questions; (b) semantic codes (connotations) include: the meaning of "looking strangely by wearing a wide headgear and wearing long clothes.", "dry leaves falling off", "sin", "magnet and he himself is like metal", "hypnotizing terrorist" his thoughts and feelings,"New York felt gray that night "; (c) symbolic codes include: symbols of wisdom, symbols of body shape; (d) proaretic code (synopsis); (e) gnomic (cultural) code including: language, history and culture.
\end{abstract}

Kata Kunci : Semiotika Roland Barthes, Novel

\begin{abstract}
Abstrak
Novel bisa menjadi media bagi pengarang untuk menuangkan permasalahan yang terdapat pada masyarakat kemudian diceritakan kembali dan menambah imajinasi sehingga bisa menarik pembaca. Novel dikatakan indah jika memuat amanat, pesan, gagasan, dan makna yang bermanfaat bagi pembaca. Novel "Tell Your Father that I am a Moslem" yang berisi, pesan, ide, dan makna yang bermanfaat bagi pembaca. Pesan akan diungkapkan oleh teori semiotika Roland Barthes, mencakup: (a) kode hermeneutik meliputi: teka-teki, rasa kesal, prasangka, respon dari berbagai peristiwa, jawaban, dan pertanyaan; (b) kode semantik (konotasi) meliputi: makna "berpenampilan aneh dengan menggunakan penutup kepala yang lebar dan mengenakan pakaian panjang.", "dedaunan kering berguguran", "dosa", "magnet dan ia sendiri ibarat logam", "teroris yang menghipnotis pikiran dan perasaannya", "New York serasa kelabu malam itu"; (c) kode simbolik meliputi: lambang kebijaksanaan, lambang bentuk tubuh; (d) kode proaretik (sinopsis); (e) kode gnomik (kultural) meliputi: bahasa, sejarah, dan budaya.
\end{abstract}

Kata Kunci : Semiotika Roland Barthes, Novel 


\section{PENDAHULUAN}

Karya sastra merupakan cerminan nyata dari masyarakat. Karya sastra disebut juga sebagai perwujudan dari kehidupan masyarakat itu sendiri yang di wakili oleh beberapa tokoh dan diatur sesuai dengan keinginan si pengarang. Pada tahap menghasilkan karya sastra ini, pengarang di tuntut lebih kreatif untuk bisa menggambarkan sesuatu dengan apa yang ia lihat dan inginkan. Apakah sesorang pengarang mampu menciptakan imajinasi yang dapat di terima dengan jelas oleh pembaca atau tidak. Hengki Kumayandi dalam novelnya yang berjudul "Tell Your Father that I am a Moslem" berupaya mengungkap berbagai masalah yang dihadapi oleh tokoh-tokohnya. Masalah yang paling utama adalah perbedaan latar belakang budaya dari hasil pemaknaan agama. Dikisahkan, seorang remaja putri muslim dari Dubai yang pindah ke Wachington DC, Amerika bersama keluarganya beradaptasi dan berhadapan dengan masayarakat disekelilingnya yang mayoritas non muslim. Remaja tersebut masuk disalah satu sekolah menengah di Amerika dan dia dihadapkan dengan kebudayaan dan pola pemikiran yang berbeda. Sejak adanya peristiwa 11 September 2001 yang terjadi di gedung putih, warga Amerika melakukan black list terhadap umat muslim. Remaja muslim tersebut mendapat penolakan dan stereotip negatif oleh teman-teman barunya. Ini merupakan sebuah ujian besar umat muslim dalam berhubungan dengan umat non muslim di Amerika.

Pada tataran praktinya, suatu masyarakat akan diketahui melalui budayanya. Secara leksikal budaya itu sendiri adalah, ilmu adab, pengetahuan dan makrifat. Sedangkan Menurut Tubbs dan Moss kebudayaan merupakan cara hidup yang dianut oleh sekelompok orang dan berkembang serta berlangsung dari generasi ke generasi ${ }^{1}$, merujuk dari pemaparan tersebut penelitian ini menggunakan kajian komunikasi antar budaya. Komunikasi antarbu daya merupakan proses pertukaran makna serta pikiran pada individu-individu yang budayanya berbeda menurut Gerhard Malatzke. Mempelajari komunikasi antarbudaya sama dengan mempelajari dan membandingkan kebiasaan setiap etnis yang berbeda-beda, agama, adat istiadat, geografis serta kelas sosial yang ada pada masyarakat. Dengan adanya pemahaman tersebut, kita dapat mengkomunikasikan perbedaan-perbedaan tersebut dengan komunikasi antar budaya ${ }^{2}$.

\footnotetext{
${ }^{1}$ Stewart L. Tubbs dan Sylvia Moss penerjemah Dr. Dedy Mulyana, M.A. dan Gembirasari, Human Communication: Prinsip-Prinsip Dasar, (Bandung: PT Remaja Rosdakarya, 1996), h. 62

2 Jurnal Ilmu Komunikasi, Adi Bagus Nugroho, Pola Komunikasi Antar Budaya Batak dan Jawa di Yogyakarta, Vol. 1, Nomor 5, Juli 2012.
}

Vol. 3, No. 1, Juni 2020, pp 17-28

Umi \& Hagi

Stereotip Islam Teroris Dalam Novel... 
Kendala yang sering di hadapi dalam proses komunikasi antar budaya adalah adanya perbedaan latar belakang. Adanya penilaian ukuran baik dan buruk maupun benar dan salah yang berbeda. Prasangka tentu akan muncul karena di picu perbedaan penilaian dan kekeliruan persepsi.Menurut Kamus Besar Bahasa Indonesia prasangka itu sendiri yakni pendapat (anggapan) yang kurang baik mengenai sesuatu sebelum mengetahui (menyaksikan,menyelidiki) sendiri ${ }^{3}$. Hal ini menunjukan sikap tersebut adalah bagian yang tidak bisa di pisahkan dari sikap seseorang kepada etnik tertentu. Peranan prasangka sangat besar terhadap terbentuknya proses komunikasi antar budaya. Prasangka inilah yang kemudian akan membentuk perilaku dan pola komunikasi yang keliru, segingga lahirlah Stereotip sebagai bentuk lain dari prasangka.

Hal yang menjadi penyebab adanya konflik antar agama, etnik dan lainya salah satunya adalah stereotip. Stereotipe yang cendrung serampangan menganggap semua anggota adalah sama dan memiliki citra yang seragam. Kecenderungan manusia, langsung mempercayai apa yang di steretipe kan dan tidak melakukan klarifikasi. Berdasarkan pengamatan peneliti, novel karangan Hengki Kumayandi di atas menyampaikan stereotip umat non muslim di Negara Amerika terhadap umat muslim di dunia. Maka penelitian mengenai Stereotip Islam Teroris Dalam Novel "Tell Your Father that I Am a Moslem" Hengki Kumayandi perlu dilakukan. Secara umum hasil penelitian ini diharapkan dapat bermanfaat untuk perkembangan ilmu komunikasi. Hal tersebut bisa dijadikan sebagai sarana penyampaian representasi kehidupan umat muslim dan umat non muslim oleh pengarang. Pembaca juga dapat mengambil kesimpulan bahwa novel sebagai sarana hiburan dan sebagai sarana memperoleh gambaran kehidupan masyarakat di sekitarnya khususnya umat muslim dinegaranegara yang mayoritas non muslim.

\section{Semiotika Roland Barthes}

Semiotika berasal dari bahasa Yunani "semeion" yang berarti 'tanda' atau seme, yang berarti "penafsir tanda"4. Semiotika kemudian didefinisikan sebagai studi tentang tanda dan cara tanda-tanda itu bekerja. Tanda merupakan pokok perhatian dari semiotika, mempunyai ciri yang khas dan penting. Pertama, tanda harus dapat dapat ditangkap dan diamati. Kedua, tanda harus menunjuk pada sesuatu yang lain, yakni sesuatu yang mampu menggantikan, mewakili dan menyajikan yang pada prinsipnya hendak mempelajari bagaimana kemanusiaan (humanity), memaknai hal-

\footnotetext{
${ }^{3}$ Depdiknas, Kamus Besar Bahasa Indonesia Edisi Keempat,. (Jakarta: Gramedia.,2008) h. 38

${ }^{4}$ Kaelan, M. S.,Filsafat bahasa Semiotika dan Hermeneutika, (Yogyakarta: Paradigma,2009), h.162
} 
hal, segala sesuatu (things). Memaknai (to sinify) dalam hal mengkomunikasikan (to communicate $)^{5}$.

Roland Barthes sendiri mengatakan bahwasanya bahasa merupakan sebuah sistem tanda yang mencerminkan asumsi-asumsi dari suatu masyarakat tertentu dalam waktu tertentu. la mengajukan pandangan ini dalam bukunya berjudul Degree Zero $^{6}$. Pendekatan yang sangat efektif untuk mengkaji budaya massa menurut Barthes adalah semiotika, karena pendekatan tersebut menjanjikan pemecahan problematika tentang kajian hubungan antara bahasa, budaya, dan ideologi, yang dijalankan lewat analisis proses dan pemaknaan. Roland Barthes mengelompokkan kode-kode cara baca menjadi lima kisi-kisi kode, yakni kode hermeunetik, kode semantik, kode simbolik, kode narasi, dan kode kultural atau kode kebudayaan. Uraian kode-kode tersebut dijelaskan sebagai berikut:

a. Kode Hermeneutik, merupakan artikulasi berbagai cara pertanyaan, teka-teki, respons, enigma, penangguhan jawaban, akhirnya menuju pada jawaban. Kode Hermeneutik berhubungan dengan teka-teki yang timbul dalam sebuah wacana. Kode ini merupakan kode penceritaan yang dapat mempertajam permasalahan suatu narasi dan menciptakan pemecahan atau jawaban. Seperti, Siapakah mereka? Apa yang terjadi? Halangan apakah yang muncul? Bagaimanakah tujuannya? Jawaban yang satu menunda jawaban lain.

b. Kode Semantik adalah tanda-tanda yang ditata sehingga memberikan suatu konotasi maskulin, feminin, kebangsaan, kesukuan, loyalitas. Kode Semantik, merupakan kode yang mengandung konotasi pada level penanda.

c. Kode Simbolik, yaitu kode yang berkaitan dengan psikoanalisis, antitesis, kemenduaan, pertentangan dua unsur, skizofrenia. Kode ini merupakan kode "pengelompokkan" atau konfigurasi yang mudah dikenali, berulang-ulang secara teratur melalui berbagai cara dan sarana tekstual

d. Kode Narasi atau Proairetik yaitu kode yang mengandung cerita, urutan, narasi atau inti narasi. Kode proaretik adalah kode tindakan atau narasi artinnya urutan-urutan dalam tindakan atau cerita. Kode ini didasarkan atas konsep proairests, yaitu kemampuan untuk menentukan hasil atau akibat dari tindakan secara rasional.

e. Kode Kebudayaan atau Kultural, yaitu suara-suara yang bersifat kolektif, anonim, bawah sadar, mitos, kebijaksanaan, pengetahuan, sejarah, moral, psikologi, sastra, seni, legenda.

${ }^{5}$ Alex Sobur, Semiotika Komunikasi, (Bandung: PT Remaja Rosydakarya, 2006), h. 15

${ }^{6}$ Ibid, h. 63

Vol. 3, No. 1, Juni 2020, pp 17-28 
Kode kultural adalah kode yang berasal dari suara- suara kolektif yang anonim dan otoritatif. Yakni berupa pengetahuan, kebijaksanaan, atau moralitas yang diterima bersama.

\section{UNSUR PEMBANGUN NOVEL}

Unsur pembangun fiksi terdiri dari tema, tokoh, alur (plot), latar (setting), sudut pandang, dan amanat:

a. Tema Menurut Nurgiyantoro tema dibedakan menjadi dua bagian ${ }^{7}$ yaitu, (1) tema utama atau tema mayor dan (2) tema tambahan atau tema minor.

b. Alur (Plot)

Alur atau plot adalah pengantar urutan peristiwa pembentuk cerita yang menunjukkan adanya hubungan kausalitas. Alur atau plot memang peranan penting dalm cerita ${ }^{8}$. Jadi, alur atau plot berguna untuk mengatur jalanya cerita, agar pembaca memahami isi cerita tersebut.

c. Tokoh

Tokoh dalam suatu karya fiksi merupakan sebuah sisi atau gambaran dari suatu struktur cerita. Tokoh adalah pelaku dalam sebuah cerita yang berperan penting dalam menampilkan suatu identitas dalam sebuah cerita. Istilah tokoh digunakan untuk menunjuk pada orangnya atau pelaku cerita. ${ }^{9}$

d. Latar (Setting)

Latar atau setting atau landas tumpu mengarah pada pengertian tempat, hubungan waktu, dan lingkungan sosial tempat terjadinya peristiwa-peristiwa ${ }^{10}$. Menurut Nurgiyantoro, membedakan unsur latar ke dalam tiga unsur pokok, yaitu: (1) latar tempat, (2) latar waktu, dan (3) latar sosial ${ }^{11}$. Latar atau setting merupakan tempat atau waktu dimana peristiwa-peristiwa itu tejadi.

e. Sudut Pandang

Sudut pandang merupakan posisi pengarang dalam sebuah cerita. Yakni penyajian tokoh, tindakan, latar, dan peristiwa yang membentuk cerita dalam sebuah karya fiksi kepada pembaca ${ }^{12}$.

\footnotetext{
${ }^{7}$ Burhan Nurgiyantoro, Penilaian dalam Pengajaran Bahasa dan sastra (Yogyakarta: PT. BFE, 2001), h. $82-83$

${ }^{8}$ Nurhayati Ginanjar, Pengkajian Prosa Fiksi Teori dan Praktik, (Diktat. Surakarta, 2012), h. 11-12

${ }^{9}$ Ibid, h. 16

10 Ibid, h.18

${ }^{11}$ Nurgiyantoro, Op.Cit, h. 227-233

${ }^{12}$ Nurgiyantoro, Ibid, h. 248

Vol. 3, No. 1, Juni 2020, pp 17-28

Umi \& Hagi

Stereotip Islam Teroris Dalam Novel... 


\section{f. Amanat}

Pesan yang disampaikan pengarang kepada pembaca melalui tokoh-tokoh yang diceritakan dalam cerita disebut amanat. Sehimgga pembaca mengetahui isi amanat/pesan dalam ceritan tersebut. Amanat atau nilai moral mengacu pada nilainilai, sikap, tingkah laku, dan sopan santun pergaulan yang dihadirkan pengarang melalui tokoh-tokoh di dalamnya ${ }^{13}$.

\section{PEMBAHASAN}

Semiotika Roland Barthers berupa kode hermeneutic, kode semantik, kode simbolic, dan kode proaretik dalam Novel Tell Your Father That I Am A Moslem Karya Hengki Kumayandi sebagai berikut:

a. Kode Hermeneutik Novel Tell Your Father That I Am A Moslem Karya Hengki Kumayandi. Hermeneutik yaitu artikulasi berbagai cara pertanyaan, teka-teki, respons, enigma, penangguhan jawaban, akhirnya menuju pada jawaban. Kode Hermeneutik juga berfungsi meng-artikulasikan pertanyaan, respon dan berbagai peristiwa yang dapat merumuskan pertanyaan dan menunda jawaban, yang membentuk suatu enigma dan membawa pada solusi titik.

Berdasarkan judul pada penelitian ini "Tell Your Father that I am a Moslem" dapat digambarkan sebagai langkah pertama dalam sebuah urutan (Hermeneutik enigma, cerita yang mengandung teka-teki. "Tell Your Father that I am a Moslem" Bilang Ayahmu Aku Seorang Muslim). Selain itu, kode hermeneutik juga terlihat dari kutipan di bawah ini.

"Di kelas ada murid baru Dave, "akhirnya Jardon Berkata.

"Hari ini teman-teman sekelas tidak masuk sekolah. Termasuk aku dan Anggel. Nico bilang dia teroris. Teman-teman takut ke sekolah. Mereka khawatir kalau-kalau sekolah kita akan dibom." Jardon berucap penuh rasa kesal. Sementara Anggel hanya diam dan menunjuk mimik wajah yang serupa dengan yang ditunjukan Jardon.

Berdasarkan kutipan di atas tampak kode hermeneutik teka-teki yang ada dalam kutipan adanya murid baru dan disebut teroris yang membuat siwa-siswi merasa khawatir dan takut sekolah mereka akan di bom.

"I should be back to school soon, then (Kalau begitu aku harus segera kembali ke sekolah). Aku tak mau sekolah kita dinodai oleh seorang teroris, tapi kata dokter aku belum boleh pulang," ucap David sedih. Sebagai ketua kelas, ia merasa menjadi orang yang paling berperan jika di kelasnya mendapatkan suatu masalah, apalagi ini tentang terorisme.

${ }^{13}$ Nurgiyantoro, Ibid, h. 321 
Pada kutipan diatas, makna hermenutik teka-teki yang ada dalam kutipan adanya rasa kesal yang ditunjukan oleh Dave yang merasa sekolahnya di nodai oleh seorang teroris.

"You don't need to be worried! I'll take care of it when you're not there. I'm your best vice, remember?! (Kau tak perlu khawatir! Aku yang akan mengatasi semuanya saat kau tak ada. Aku, kan, wakilmu)" Sergah Jardon dengan senyum.

"Terima kasih Jardon, cepatlah bertindak, kalau tidak nanti sekolah kita bias porak-poranda seperti Gedung Putih!" Pinta David penuh semangat

Berdasarkan kutipan dia atas, nampak dengan penggunaan kode hermeneutik respon dan berbagai peristiwa yaitu adanya rasa persahabatan yang kuat antara Jordan dengan Dave yang siap saling membantu untuk mengatasi kesulitan.

"A terrorist?" David terkejut tak percaya.

Dari kutipan diatas, hermeneutik enigma pada kalimat tersebut berupa pertanyaan. Seorang teoriris?

"Mereka pikir aku seorang teroris, Pak, padahal aku pindah ke sini jauh-jauh dari Dubai karena ikut ayahku yang bertugas sebagai duta besar Uni Emirat Arab. Aku hanya seorang siswi, bukan teroris." Maryam berusaha menjelaskan.

Berdasarkan kutipan dia atas, nampak dengan penggunaan kode hermeneutik jawaban tampak pada pernyataan Maryam yang menjelaskan bahwa dirinya bukan teroris.

"Begitu, ya?" ucap Guru itu, lalu mendekat ke arah David, "This is your resposibility as the chief of the class. You must convince and explain to your friends that Maryam is not a terrorist. (Ini tanggung jawabmu sebagai ketua kelas. Kau harus meyakinkan dan menjelaskan pada semua temanmu bahwa Maryam bukan teroris."

Dari kutipan diatas, penggunaan kode hermeneutik teka-teki terlihat dari bagaimana dave diminta untuk meyakinkan siswa-siswi yang lain bahwa Maryam bukan teroris.

b. Kode Semantik Novel Tell Your Father that I am a Moslem Karya Hengki Kumayandi. yaitu kode yang mengandung konotasi pada level penanda. Misalnya konotasi feminitas, maskulinitas, yakni tanda-tanda yang ditata yang kemudian memberikan konotasi tertentu seperti feminin, maskulin, kebangsaan, kesukuan. Jika melihat kumpulan suatu konotasi dengan menemukan suatu tema di dalam cerita. Sejumlah konotasi melekat pada suatu nama tertentu, dapat mengenali suatu tokoh dengan atribut tertentu. Makna yang di tafsirkan dalam kalimat merupakan makna konotatif. Hal ini terlihal dari beberapa kutipan di bawah ini. 
"lya, Dave. Semua anak di kelas ingin menuntut Kepala Sekolah agar mengeluarkan anak itu. You know what? She always wears a long dress and a big veil, kinda awkward outfit. Yuck! (Kau tahu? Dia kerap mengenakan pakaian panjang dan kerudung kebesaran, kostum yang aneh sekali. Yuck!)" Tukas Anggel meyakinkan.

Berdasarkan kutipan di atas, makna konotatif terdapat dalam kalimat berpenampilan aneh dengan menggunakan penutup kepala yang lebar dan mengenakan pakaian panjang. Memiliki arti pakaian Muslimah yang dikenakan oleh seorang muslim.

Dedaunan kering berguguran di sepanjang jalan trotoar menuju halte bus. Kota New York begitu hangat siang ini. Maryam berjalan menunduk menuju halte.

Berdasarkan kutipan di atas, makna konotatif yang ada dalam kutipan dedaunan kering berguguran mengandung makna hidup tidaklah ada yang abadi, keadaan pasti akan selalu berubah kapanpun dna dimanapun.

"Ya Allah, jika ini dosa, ampuni aku..."Bisik hati Maryam

Berdasarkan kutipan di atas, kode semantik yang terkandung dalam kutipan adalah ketakutan seorang gadis yang melakukan kesalahan dan akan mendapatkan hukuman.

"Untuk pertama kalinya selama ia hidup, David merasa wajah Maryam seperti magnet dan ia sendiri ibarat logam yang tak mau lepas dari magnet itu."

Berdasarkan kutipan di atas, makna konotatif yang ada dalam kutipan adalah wajah Maryam seperti magnet dan ia sendiri ibarat logam mengandung makna Maryam mampu menarik perhatian devid sehingga dia tidak bisa jauh dari Maryam.

"David merasa gadis ini memang seorang teroris, tapi teroris yang menghipnotis pikiran dan perasaannya untuk selalu mengingat parasnya."

Berdasarkan kutipan di atas, kode semantik yang terkandung dalam kutipan seorang teroris, tapi teroris yang menghipnotis pikiran dan perasaannya mengandung makna seseorang yang melakukan tindak kekerasan demi tujuan tertentu dan selalu mempengaruhi alam bawah sadarnya lewat pikiran dan perasaan sehingga selalu mengingatnya.

"New York serasa kelabu malam itu. Hati David sakit."

Berdasarkan kutipan di atas, merupakan kode semantik frasa kelabu memiliki arti yang sebenarnya mengandung penafsiran kesedihan, kerinduan, duka dan kehilangan, yang dalam kutipan diatas membuat hati David sakit.. 
c. Kode Simbolik Novel Tell Your Father that I am a Moslem Karya Hengki Kumayandi. yaitu kode yang berkaitan dengan psikoanalisis, antitesis, kemenduaan, pertentangan dua unsur, skizofrenia. Kode ini merupakan kode "pengelompokkan" atau konfigurasi yang mudah dikenali, berulang-ulang secara teratur melalui berbagai cara dan sarana tekstual. Kode simbolik biasanya menggunakan bahasa sastra yang mengungkapkan atau melambangkan suatu hal dengan hal lain. Peristiwa-peristiwa yang dilukiskan dalam puisi belum tentu bermaksud dalam hanya dalam cerita. Bahkan mungkin merupakan lambang suatu kejadian. Hal ini terlihat dari kutipan di bawah ini.

"lbu belum begitu mengerti, tapi menurut desas-desus yang ibu tahu dari perbincangan mereka, mereka pikir kamu seorang teroris, padahal ibu sudah menjelaskan panjang lebar bahwa kau anak seorang duta besar dari Uni Emirat Arab. Tapi jangan khawatir, mereka akan ibu urus. Walau hanya kau sendiri yang hadir di kelas ini, kegiatan belajarmengajar harus tetap berlangsung," ucap Bu Violen sambil tersenyum menjelaskan pada Maryam. Guru berkulit hitam dan berambut keriting itu terlihat sangat bijak.

Berdasarkan kutipan di atas, terlihat jelas menggambarkan bagaimana seorang guru berkulit hitam dan berambut keriting yang bijak dan berusaha memberikan penjelasan kepada siswa-siswinya bahwa kawan mereka bukan seorang teroris tetapi anak seorang duta besar dari Uni Emirat Arab, dan tetap melanjutkan pelajaran dalam kelas walaupun hanya satu siswa yang datang.

"Lelaki berambut ikal pirang dan bermata biru itu tersenyum lalu berjalan mendorong sepedanya. Kini giliran Maryam yang mengekor. Tak lama kemudian David terhenti. la berbalik menghadap Maryam, Maryam pun langsung menunduk."

Berdasarkan kutipan di atas, menggambarkan bentuk tubuh devid yang memiliki rambut ikal pirang dan bermata biru.

“David terperangah, sosok wanita berwajah cerah itu terus menunduk. Matanya yang bening biru, hidungnya yang mancung, serta alisnya yang tebal dan menyatu membuat David diam terpaku"

Berdasarkan kutipan di atas, terlihat jelas menggambarkan sosok wanita yang cantik dengan matanya yang bening biru, hidungnya yang mancung, serta alisnya yang tebal dan kecantikan itu dimiliki oleh Maryam.

d. Kode Proaretik Novel Tell Your Father that I am a Moslem Karya Hengki Kumayandi proaretik atau kode tindakan yaitu kode yang mengandung cerita, urutan, narasi atau inti narasi. Konsep proairests yang mendasari kode tersebut, yaitu akibat dari tindakan secara rasional atau kemampuan dalam menentukan hasil. urutan, narasi atau anti

Vol. 3, No. 1, Juni 2020, pp 17-28 
narasi. Adapun kode proaretik novel Tell Your Father That I Am A Moslem Karya Hengki Kumayandi tampak pada kalimat dibawah ini.

"Tell Your Father that I am a Moslem"

(Bilang Ayahmu Aku Seorang Muslim)

Berdasarkan kutipan di atas, penulis karya sastra bermaksud menyampaikan pikirannya lewat kata yang membuat pembaca penasaran. Adapun nasari dari Novel ini menceritakan kisah dua remaja yang berbeda agama yaitu Maryam sebagai seorang muslim dan David sebagai umat non muslim. Maryam adalah anak seorang Duta Besar Uni Emirat untuk Amerika yang terpaksa pindah ke Amerika karena tuntutan pekerjaan orang tuanya. Maryam dan keluarganya pindah dari Dubai ke Amerika untuk meneruskan kehidupanya. Perbedaan budaya dan agama membuat keluarga tersebut tekhusus bagi Maryam terkena culture shock. Maryam yang sedari kecil tinggal dan sekolah bersama lingkungan yang muslim kini harus berhadapan dengan lingkungan non muslim. Tidak hanya itu, dia juga dihadapkan pada sebuat prasangka negatif tentang Islam dari masyarakat Amerika. Peristiwa 11 September 2001 menjadi sejarah kelam Amerika dimana gedung putih dihancurkan oleh terosris dan setelah kejadian itu masyarakat Amerika langsung memblack list umat muslim. Masyarakat amerika memandang buruk dan murka terhadap umat muslim serta mengganggap semua muslim adalah teroris. Pada sisi lain warga sesungguhnya seorang muslim sejati tidak akan pernah melakukan kehancuran di bumi. Dan orangorang yang melakukan kehancuran itu bukan termasuk kedalam muslim sejati.

Hal inilah yang membuat Maryam tertekan saat memasuki lingkungan baru seperti disekolah. Maryam telah menjadi murid baru di salah satu sekolah menegah di Amerika. Maryam merupakan satu-satunya siswi muslim di kelasnya. Saat pertama Maryam di kelas, ia mendapat penolakan yang hebat. la hanya bisa terdiam. Temanteman di kelasnya melontarkan cacian dan makian kepadanya dengan sebutan teroris. Tidak sampai disitu, teman-temanya berniat ingin memprotes kepada kepala sekolah dan menuntut mengeluarkan Maryam. Maryam hanya bisa terdiam dan merunduk tak berani menatap teman-temanya. Sekarang ia benar-benar sendiri. Meski waktu telah berjalan selama tiga hari, Maryam tetap sekolah meski teman-temanya meninggalkan kelas karenanya. Namun, selama iya masuk sekolah, ternyata ada seorang siswa yang belum bisa hadir karena ia sedang sakit. Namanya David, david meruapakan ketua kelas Maryam. David sedang dirawat di rumah sakit dan ia belum diperbolehkan pulang meski dirinya sudah ingin bertemu dengan teman-temanya. Selama david tidak

Vol. 3, No. 1, Juni 2020, pp 17-28 
masuk, Jordon wakilnya selalu menjenguk dan memberikan informasi tentang situasi di kelas. Jordon membeberkan tentang siswi baru yang menakutkan, siwi yang dianggapnya sebagai teroris. Mendengar penjelasan Jordon, David pun terbakar dan ingin segera mengusir siswi tersebut.

Singkat cerita David sudah sehat dan diperbolehkan sekolah. Sesampainya di sekolah David langsung mencari Maryam dengan penuh amarah. Saat Maryam hadir di depanya, David memperhatikan keseluruhan Maryam. Tiba-tiba seperti terhipnotis david berubah pikiran. la justru tidak menganggap Marya teroris karena melihat kecantikan wajahnya. Jordon dan teman-temanya tidak percaya David bisa berubah sevcepat itu. Dalam pertengahan cerita David menjadi sosok yang menemani Maryam ditengah-tengah diskriminasi yang dilakukan teman-temanya. David sangat penasaran terhadap maryam hingga diahir cerita David mampu bersatu dengan Maryam.

e. Kode Gnonik (kultural) Novel Tell Your Father that I am a Moslem Karya Hengki Kumayandi adalah Kode Kebudayaan atau Kultural, yakni suara yang bersifat kolektif, kebijaksanaan, anonim, moral, psikologi, bawah sadar, mitos, pengetahuan, sejarah, sastra, legenda yang diterima bersama seni, misalnya kesucian, kesakralan, atau baik dan buruk. Adapun kode kultural dalam novel tell your father that I am a Moslem tampak pada kalimat di bawah ini.

"Mereka pikir aku seorang teroris, Pak, padahal aku pindah ke sini jauh-jauh dari Dubai karena ikut ayahku yang bertugas sebagai duta besar Uni Emirat Arab. Aku hanya seorang siswi, bukan teroris." Maryam berusaha menjelaskan

Dari kutipan di atas, menunjukkan kode sejarah dimana Maryam menjelaskan asal usul dirinya yang anak seorang duta emirate arab dan pindah ke new York karena ayahnya ditugaskan di new York dan dirinya bukan seorang teroris, seperti anggapan temantemannya. Maryam merasa bangga melihat gurunya sudah hafal namanya. "Good Morning, Mom. Kenapa teman-teman di kelas ini tidak hadir?" tanya Maryam yang masih belum begitu sempurna bahasa Inggrisnya. Logat bahasa Arabnya masih kental sehingga mempengaruhi ucapan bahasa Inggrisnya. Sebenarnya dari kecil Maryam sudah dikursuskan bahasa Inggris oleh ayahnya sehingga dia tidak begitu kesulitan dalam bahasa tersebut, hanya logatnya saja yang kadang terdengar belum pas. Dari kutipan di atas, menunjukkan kode budaya, dimana Maryam yang dalam pengucapan bahasa inggrisnya masih menggunakan logat bahasa arab yang masih kental. 


\section{SIMPULAN}

Novel Hengki Kumayandi yang berjudul "Tell Your Father that I am a Moslem" merupakan novel fiksi Islami menerangkan berbagai masalah yang dihadapi oleh tokoh-tokohnya. Hengki menggunakan tokoh utama, Maryam. Melalui tokoh tersebut dalam novel Novel Tell Your Father that I am a Moslem, mengungkapkan kegelisahan masyarakat non muslim di Amerika terhadap kehadiran umat muslim yang mereka cap sebagai teroris. Penelitian ini bertujuan untuk mengetahui bagaimana representasi budaya stereotip Islam Teroris. Berdasarkan analisis yang dilakukan oleh penulis dengan menggunakan teori semiotika Roland Barthes dal novel Tell Your Father that I am a Moslem meliputi ;(1) kode hermeneutik, (2) kode semik (kode konotatif); (3) kode simbolik (4) kode preoretik (kode tindakan), (5) kode gnomik (kultural) semisal menceritakan sesuatu dengan contoh kisal masa lalu atau legenda. Dari penelitian tersebut, maka penulis menyimpulkan bahwa stereotip Islam Teroris dipresentasikan melalui penampilan yang aneh dengan menggunakan kerudung dan menggunakan hijab panjang.

\section{DAFTAR PUSTAKA}

Alex Sobur, Semiotika Komunikasi, Bandung: PT Remaja Rosydakarya, 2006

Burhan Nurgiyantoro, Penilaian dalam Pengajaran Bahasa dan sastra, Yogyakarta: PT. BFE, 2001.

Depdiknas, Kamus Besar Bahasa Indonesia Edisi Keempat, Jakarta: Gramedia.,2008. Jurnal Ilmu Komunikasi, Adi Bagus Nugroho, Pola Komunikasi Antar Budaya Batak dan Jawa di Yogyakarta, Vol. 1, Nomor 5, Juli 2012.

Kaelan, M. S.,Filsafat bahasa Semiotika dan Hermeneutika, Yogyakarta: Paradigma,2009.

Nurhayati Ginanjar, Pengkajian Prosa Fiksi Teori dan Praktik, Diktat. Surakarta, 2012.

Stewart L. Tubbs dan Sylvia Moss penerjemah Dr. Dedy Mulyana, M.A. dan Gembirasari, Human Communication: Prinsip-Prinsip Dasar, Bandung: PT Remaja Rosdakarya, 1996. 